it would all come to that in the end-that is, that it would all come for every body to get advice and medicine gratuitously. Matters certainly so tend to this result that there appears need of either an act of parliament excluding from within the pale of the medical profession all men possessed of an independent income of less than $£ 300$ a year, or else an act making it " in England a misdemeanour, and in Scotland a crime and an offence," for any medical man to undertake any public office without being well paid for it.

I am. Sir, your obedient servant.

To Mr. David Cope, Secretary to the S. GowER, M.R.C.S.E., \&c. Lying-in Infirmary, Birmingham.

PROFESSIONAL QUACKERY AND ITS CAUSES.-A CONTRAST OF THE MEDICAL AND LEGAL PROFESSIONS.

\section{To the Editor of The Lavcer.}

SrR,-As long as we have such things as Lambeth Beck's Specific Mixture, and Liverpool Taylor's College for the Cure of Cancer; as long as we have men like the Upton-on-Severn applicants, who prove traitorous to the true dignity and welfare of th+ir profession, Mr. O'Shea has every right to designate such doings as " the gross blackguardism that is practised in the profession," and the public has every right to reiterate his ha! ha! ha!

How is it, Mr. Editor, that the profession of medicine in this country teems with men who descend to the most corrupt practices? How is it that it can so ill bear to be contrasted with its sister profession, the law? One would reasonably expect, that the profession of medicine, having nobler ends to secure than the legal profession, would possess a fuller measure of public esteem and respect. Yet contrast the twocan there be a doubt which profession is freer from abnses, which derives more honour from the respectability of its members.

I think, Mr. Editor, the remote cause of this rottenness may be traced to the introduction of men into the ranks whose early education and position in life has not been such as to fit them for the liberal exercise of a profession. The more immediate cause, is the necessity of living, urging such men to pursue a line of conduct which, though unbecoming and strictly unprofessional, is entered upon without reserve.

The law, in her wisdom, has prevented the influx of men into her ranks, who, from education and position in life, were not likely to uphold the interests of the profession by a liberal practice.

To this end, the stamp duty and fee amount to such a sum, that no parent who is not himself in a position which would guarantee a good education to his children, could afford to place a son in the law. The consequence is, that members of the legal profession are drafted from families whose position in life ensures to their children that sort of education and those advantages which accrue from a uniform class-appreciation of what is becoming and correct.

The facility with which a young man can gain admittance into the medical profession has opened the door to the ambition of many a petty tradesman, who fancies that, by putting his son into a profession, he can "make a gentleman" of him. He is just able to pay the first expense-the apprenticeship; the young man (who has never associated with educated people, and cannot be expected to have the ideas and feelings which bclong to this class) passes through a term of five years in a sort of servant-like drudgery, which is calculated to lower rather than to elevate his inind. The period arrives when he ought to enter the schools, and his friends then learn, that the expense of walking the hospitals, as it is called, will be quite as much, if not more than they can compass; at all events, the youth is told that from the very day he obtains his diploma he must gain his own bread. What follows? He finds that men in the professions of law and medicine must pass through a state of probation, which may extend over weeks, and months, and possibly over years. His object is to cut this term short. Does he manifest any reluetance to engage in pursuits unbecoming a professional man, or likely to reflect on the profession of which he has become a member? Assuredly not! to him such feelings are foreign; he cannot understand them; his sole object is to obtain a living, and all means are expedient to this end which are not actually unlawful.

This is a true picture of the career of hundreds of members of the profession of medicine in this country. How little could such men enter into the spirit of the following, from the pen of Lord Bacon:-" I hold every man a debtor to his profession, from which, as men of course do seek to receive countenance and profit, so ought they, of daty, to endeavour themselves, by way of amends, to be a help and ornament thereunto. This is performed, in some degree, by the honest and liberal practice of a profession, when men shall carry a respect not to descend into any course which is corrupt and unworthy thereof, and preserve themselves free from the abuses wherewith the same profession is noted to be infected."

In 55 Geo. III. cap. 184, we find:- " The sum of money, or the value paid with or in respect of an apprentice, shall, if the amount be under $£ 30$, be $£ 1$; if above $£ 30$ and under $£ 50$, $£ 2$; if above $£ 50$ and under $£ 100, £ 3$; if above $£ 100$ and under $£ 200, £ 6 . "-$ N.B. $£ 50$ is a very common apprenticeship fee.

The first admission to the legal profession stands thus:"Articles of clerkship, whereby a person shall first become bound as a clerk, in order to his admission as an attorney or solicitor, stamp-duty £120, for any of her Majesty's courts of Westminster." - 55 Geo. III. cap. 184.

In addition to this sum, no respectable office in the country receives a less fee than $£ 200$ with such clerk, and the fee generally given is $£ 300$. The attorney, moreover, pays to the crown, during the first four years of practice, $£ 4$ per annum for his certificate; and he afterwards pays $£ 8$ per annum, so long as he continues to practise his profession.

I hope, Mr. Editor, you will use the great influence you possess in endeavouring to alter the present mode by which a man enters the profession; the apprenticeship system has been a great curse; I trust it may be done away with altogether; and that medical education may be extended over a term requiring a residence of full five years; no youth being allowed to matriculate before the age of nineteen. I am, Sir, your obliged servant,

August 9th, 1848

Filios Machaonis.

\section{fftedical $\$$ Hefns.}

A pothecaries' Hall.-Names of gentlemen who passed their examination in the science and practice of medicine and received certificates to practise, on Thursday, 24 th Angust, 1848:-William John Player, Swansea; William Richard Hilton, Whitehaven, Cumberland.

Medical Matters in the United States.-At a late meeting of the onnecticut Medical Society, a resolution to the following effect was laid on the table for consideration:"That, as it has been customary to render medical services to clergymen and their families gratuitously, and as it is believed that, as a class, their education, intelligence, and moral standing considered, they do more than any other class to embarrass the legitimate influence of the medical protession; theretore, resolved, that we adopt the practice of charg. ing clergymen the same fees as other citizens, except in cases of misfortune and inability."-The New York Thompsonian, the only paper advocating the pretensions of that humbug (homœopathic) sect, has been discontinued, and the editor states that the sect was never before at so low an ebb as at present. He thinks, however, that there is still vitality enough " to put on the steam of everlasting truth" and "set in motion again the car of medical reform."-The State of Pennsylvania has authorized the Homœopathic College in Pennsylvania to grant diplomas.-The Boston Medical Journal says that a galvanic ring mania is quite epidemic in New England. They not only cover their fingers and necks with them, but their toes are not exempted from their application. - (Quoted in the Dublin Medical Press.)

SuRgery in British Indra.-The published reports of the Government Charitable Dispensaries exhibits the following catalogue of severe surgical operations performed by Native sub-assistant surgeons, with their results:-

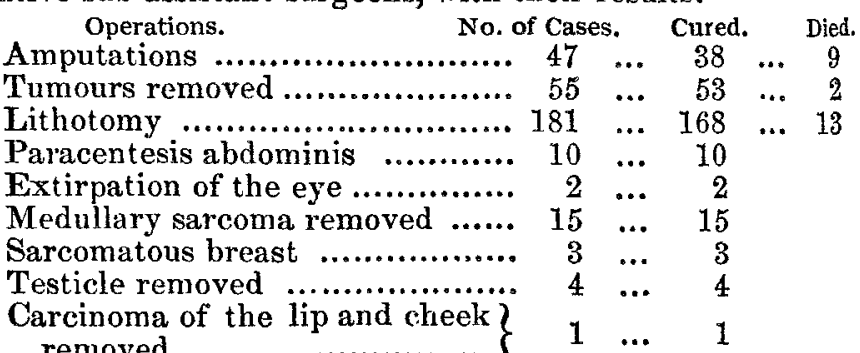

This is independent of a multitude of minor operations, and thousands of succerssful medical cases, embracing the most formidable endemic and epidemic diseases of the country as well as in the private practice of the passed students settled 